JURNAL KETAHANAN NASIONAL

Vol. 25, No. 3, Desember 2019, Hal 393-408

DOI:http://dx.doi.org/ 10.22146/jkn.50652

ISSN:0853-9340(Print), ISSN:2527-9688(Online)

Online sejak 28 Desember 2015 di :http://jurnal.ugm.ac.id/JKN

VOLUME 25

No. 3, Desember 2019

Halaman 393-408

\title{
Relevansi Sumber Belajar Ketahanan Nasional Mata Pelajaran Pendidikan Pancasila Dan Kewarganegaraan Dengan Indikator Pencapaian Kompetensi Siswa (Studi Di Sma Negeri 1 Surakarta, Jawa Tengah)
}

\author{
Wijianto \\ Universitas Sebelas Maret Surakarta, Indonesia \\ Email: wijianto@staff.uns.ac.id \\ Muhammad Hendri Nuryadi \\ Universitas Sebelas Maret Surakarta, Indonesia \\ Email: hendri_uns@yahoo.com \\ Siska Nurdiani \\ Universitas Sebelas Maret Surakarta, Indonesia \\ Email: siskanurdiani@student.uns.ac.id
}

\begin{abstract}
This study aimed to determined: 1). The availability of national resilience learning resources for Civic Education subjects; 2). Relevance of learning resources for national resilience in Civic Education subjects with indicators of student competency achievement; and 3). The obstacles experienced by teachers in the use of national resilience learning resources for Civic Education subjects.

The study used a qualitative approach that was strengthened by quantitative data. Data collection using interviews, observation, study documents, and questionnaires. Data validity testing used data triangulation and method triangulation. Data analysis used an interactive analysis model.

The results of the study were: 1). The availability of national resilience learning resources for PPKn subjects was quite adequate because there were available Student Books, Student Worksheet, and websites as a source of material for threats to the Republic of Indonesia. 2). Material to Be Wary of Threats to the Republic of Indonesia on learning resources for national resilience in PPKn subjects, especially Student Books, Student Worksheet, and the website did not meet the indicators of student competency achievement because the material only presented civic knowledge and civic disposition, while civic skills had not been fully presented because they only fulfilled intellectual skills while participatory skills had not yet been fulfilled. 3). The obstacle of teachers in the use of national resilience learning resources for PPKn subjects for Student Books and Student Worksheet, e.i there was wrong material and the extent of the lacking material. The website was constrained by wifi signals and some contain invalid information.
\end{abstract}

Keywords: Learning Resources, National Resilience, Competence Achievement Indicators of Students, Civic Education.

\section{ABSTRAK}

Penelitian ini bertujuan untuk mengetahui: 1) ketersediaan sumber belajar ketahanan nasional mata pelajaran PPKn; 2) relevansi sumber belajar ketahanan nasional mata pelajaran PPKn dengan indikator pencapaian kompetensi siswa; dan 3) kendala yang dialami guru dalam pemanfaatan sumber belajar ketahanan nasional mata pelajaran PPKn. 
Tabel 3

Lembar Pengamatan Untuk Materi Yang Disampaikan Guru PPKn

\begin{tabular}{|c|c|c|c|c|}
\hline \multirow{2}{*}{ Aspek Pengamatan } & \multirow{2}{*}{ Indikator } & \multicolumn{3}{|c|}{ Skor } \\
\hline & & 1 & 23 & 4 \\
\hline \multirow{3}{*}{$\begin{array}{l}\text { Relevansi sumber belajar PPKn } \\
\text { dengan indikator pencapaian } \\
\text { kompetensi siswa }\end{array}$} & $\begin{array}{l}\text { 1. Guru dalam mengajar materi pelajaran menekankan aspek } \\
\text { pengetahuan kewarganegaraan. }\end{array}$ & & & $\sqrt{ }$ \\
\hline & $\begin{array}{l}\text { 2. Guru dalam mengajar materi pelajaran menekankan aspek } \\
\text { sikap kewarganegaraan. }\end{array}$ & & $\sqrt{ }$ & \\
\hline & $\begin{array}{l}\text { 3. Guru dalam mengajar materi pelajaran menekankan aspek } \\
\text { keterampilan kewarganegaraan. }\end{array}$ & $\sqrt{ }$ & & \\
\hline
\end{tabular}

Catatan:

Sumber: Dokumen Peneliti, 2019

4 = selalu, apabila selalu melakukan sesuai pernyataan

3 = sering, apabila sering melakukan pernyataan dan kadang-kadang tidak melakukan

2 = kadang-kadang, apabila kadang-kadang melakukan dan sering tidak melakukan

$1=$ tidak pernah, apabila tidak pernah melakukan

Tabel 4

Tabulasi Presentase Materi Yang Disampaikan Guru PPKn

\begin{tabular}{|c|c|c|c|c|c|}
\hline \multirow[t]{2}{*}{ No. } & \multirow[t]{2}{*}{ Pernyataan } & Selalu & Sering & $\begin{array}{l}\text { Kadang- } \\
\text { Kadang }\end{array}$ & $\begin{array}{r}\text { Tidak } \\
\text { Pernah } \\
\end{array}$ \\
\hline & & \multicolumn{4}{|c|}{$\%$} \\
\hline 1. & Kompetensi pada aspek pengetahuan & 45 & 47,5 & 7,5 & 0 \\
\hline 2. & Kompetensi pada aspek sikap & 40 & 57,5 & 2,5 & 0 \\
\hline 3. & Kompetensi pada aspek keterampilan & 35 & 57,5 & 7,5 & 0 \\
\hline 4. & $\begin{array}{l}\text { Isi dari sumber belajar sudah memenuhi syarat dalam } \\
\text { menjelaskan materi pelajaran }\end{array}$ & 25 & 67,5 & 7,5 & 0 \\
\hline
\end{tabular}

Sumber: Dokumen Peneliti, 2019

pada aspek kognitif, afektif dan psikomotorik. Adapun hasil lembar pengamatan materi yang disampaikan guru ditunjukkan pada tabel 3 .

Berdasarkan hasil lembar pengamatan tersebut dapat ditunjukkan bahwa guru dalam mengajarkan materi Mewaspadai Ancaman Terhadap NKRI selalu menekankan pada aspek pengetahuan karena guru memberikan informasi terkait materi yang disampaikan. Guru dalam mengajar pun sering menekankan pada aspek sikap sesuai materi. Namun, guru kadang-kadang dalam menekankan aspek keterampilan.

Selain itu, untuk memperkuat hasil observasi tentang relevansi sumber belajar PPKn kelas XI dengan indikator pencapaian kompetensi siswa di SMANegeri 1 Surakarta, maka peneliti menyebar angket kepada beberapa siswa. Berikut, tabel 4 merupakan hasil angket sebagai gambaran materi yang diberikan guru pada saat pembelajaran PPKn.

Berdasarkan tabel 4 tersebut dapat disimpulkan bahwa guru saat mengajarkan materi selalu menekankan pada aspek pengetahuan sebanyak $45 \%$, aspek sikap $40 \%$, dan aspek keterampilan 35\%. Hal ini menunjukkan bahwa dalam mengajarkan materi guru paling dominan menekankan aspek pengetahuan dibandingkan dengan aspek sikap, dan keterampilan.

Lebih lanjut, penilaian rencana pelaksanaan pembelajaran (RPP) di SMAN I Surakarta kelas XI dengan kompetensi dasar : 3.5 mengkaji kasus-kasus ancaman terhadap 
Penelitian menggunakan pendekatan kualitatif yang diperkuat data kuantitatif. Pengumpulan data menggunakan wawancara, observasi, studi dokumen, dan angket. Pengujian validitas data menggunakan triangulasi data dan triangulasi metode. Analisis data menggunakan model analisis interaktif.

Hasil penelitian ini yaitu: 1). Ketersediaan sumber belajar ketahanan nasional mata pelajaran PPKn cukup memadai karena tersedia Buku Siswa, LKS, dan website sebagai sumber materi ancaman terhadap NKRI. 2). Materi Mewaspadai Ancaman terhadap NKRI pada sumber belajar ketahanan nasional mata pelajaran PPKn, khususnya Buku Siswa, LKS, dan website belum memenuhi indikator pencapaian kompetensi siswa karena materi hanya menyajikan civic knowledge dan civic disposition, sementara civic skill belum sepenuhnya disajikan karena baru memenuhi intellectual skills sedangkan participatory skills belum terpenuhi. 3). Kendala guru dalam pemanfaatan sumber belajar ketahanan nasional mata pelajaran PPKn untuk Buku Siswa dan LKS, yaitu terdapat materi yang keliru dan keluasan materinya kurang. Website terkendala sinyal wifi dan beberapa memuat informasi tidak valid.

\section{Kata Kunci: Sumber Belajar, Ketahanan Nasional, Indikator Pencapaian Kompetensi Siswa, PPKN.}

\section{PENGANTAR}

Konsepsi tentang ketahanan nasional (national resilience) merupakan salah satu konsepsi kenegaraan Indonesia. Ketahanan sebuah bangsa pada dasarnya dibutuhkan guna menjamin serta memperkuat kemampuan bangsa yang bersangkutan baik dalam rangka mempertahankan kesatuannya, menghadapi ancaman, gangguan, maupun mengupayakan sumber daya guna memenuhi kebutuhan hidup (Agus, 2015: 247). Upaya untuk mewujudkan ketahanan nasional dapat dilakukan melalui bela negara. Istilah bela negara, dapat ditemukan dalam rumusan Pasal 27 ayat 3 UUD NKRI 1945. Pasal 27 ayat 3 menyatakan "Setiap warga negara berhak dan wajib ikut serta dalam upaya pembelaan negara". Selain itu, setiap warga negara dapat turut serta dalam setiap usaha pembelaan negara sesuai dengan kemampuan dan profesi masingmasing. Dalam Undang-Undang Nomor 3 Tahun 2002 tentang Pertahanan Negara pasal 9 ayat 1 disebutkan bahwa "Setiap warga negara berhak dan wajib ikut serta dalam upaya bela negara yang diwujudkan dalam penyelenggaraan pertahanan negara". Bela negara dapat dibedakan secara fisik maupun non fisik. Secara fisik dapat disamakan dengan bela negara dalam arti militer. Sedangkan bela negara secara non fisik dapat didefinisikan sebagai segala upaya untuk mempertahankan Negara Kesatuan Republik Indonesia dengan cara meningkatkan kesadaran berbangsa dan bernegara, menanamkan kecintaan terhadap tanah air serta berperan aktif dalam memajukan bangsa dan negara, termasuk penanggulangan ancaman. Bela negara demikian dapat dipersamakan dengan bela negara secara nonmiliter.

Kondisi karakter bangsa Indonesia saat ini, dengan munculnya berbagai permasalahan dalam berbagai aspek kehidupan seperti terorisme, radikalisme, dan acaman lainnya terhadap NKRI menggambarkan indikasi mulai terkikisnya rasa nasionalisme dan erosi ideologi kebangsaan yang begitu komplek (Winarno, 2013: 99). Salah satu upaya untuk mengatasi berbagai permasalahan di bidang ketahanan nasional ini adalah menginternalisasikan nilai-nilai bela negara melalui pendidikan. Pendidikan yang berkaitan erat dengan upaya bela negara adalah PPKn (Pendidikan Pancasila dan Kewarganegaraan). PPKn merupakan salah satu bidang kajian dalam konteks pendidikan nasional yang memiliki peran strategis untuk meningkatkan kembali wawasan kebangsaan dan semangat nasionalisme generasi muda. Dalam rangka memperkuat peran Pendidikan Pancasila dan Kewarganegaraan, maka pemerintah 
Wijianto, Muhammad Hendri Nuryadi, Siska Nurdiani -- Relevansi Sumber Belajar Ketahanan Nasional Mata Pelajaran Pendidikan Pancasila Dan Kewarganegaraan Dengan Indikator Pencapaian Kompetensi Siswa

(Studi Di Sma Negeri 1 Surakarta, Jawa Tengah)

mewajibkan diberikan pada setiap satuan pendidikan, sebagaimana dalam pasal 37 ayat (1) Undang-Undang No. 20 Tahun 2003 tentang Sistem Pendidikan Nasional bahwa "Pendidikan Kewarganegaraan dimaksudkan untuk membentuk peserta didik menjadi manusia yang memiliki rasa kebangsaan dan cinta tanah air". Pendidikan kewarganegaraan sebagai salah satu mata ajar yang berbasis nilai akan menjadi salah satu alternatif dalam mengembangkan karakter peserta didik (Permata, 2012: 1).

Pencapaian tujuan nasional tersebut tentu memerlukan dukungan dari banyak pihak. Selain dari pemerintah, diperlukan juga guru sebagai pelaksana teknis proses pembelajaran di lapangan. Maka, dibutuhkan guru yang berkompeten. Menurut UndangUndang Nomor 14 Tahun 2005 Tentang Guru dan Dosen Pasal 10 Ayat 1 menegaskan, "Kompetensi guru terdiri dari empat kompetensi, yaitu pedagogik, kepribadian, sosial, dan profesional". Guru yang memiliki semua kompetensi sangat mempengaruhi keberhasilan siswa dalam belajar (Ushani, 2017: 8). Namun, tidak semua guru memiliki kompetensi yang mumpuni, problematika guru dalam peningkatan kompetensi disebabkan karena keterbatasan waktu yang dimiliki guru, rendahnya motivasi dalam melakukan suatu penelitian, dan terbatasanya pengetahuan guru (Julaikah, 2017: 1). Salah satu faktor penyebab menurunnya kualitas pendidikan pada jenjang pendidikan menengah yaitu kurangnya daya dukung dari sumber daya guru profesional (Kartowagiran, 2011: 472). Keempat kompetensi guru tersebut tentu dapat berkembang melalui berbagai pelatihan, penelitian tindakan kelas, serta pemanfaatan sumber belajar yang bervariasi (Juniantari, 2017: 10).
Tugas guru yang umumnya dilakukan di satuan pendidikan adalah perencanaan, pelaksanaan, dan evalusi pembelajaran. Hal ini terutama berkaitan dengan kompetensi profesional guru. Kompetensi profesional guru salah satunya yaitu mampu menggunakan berbagai komponen pembelajaran diantaranya, media, fasilitas, dan sumber-sumber belajar lainnya secara efektif (Mulyasa, 2013: 69). Berhubung sumber belajar mengandung materi pelajaran maka kompetensi profesional guru menjadi poin utama dalam ranah ini. Kompetensi profesional adalah kemampuan untuk menguasasi materi pelajaran yang diampunya. Tujuannya adalah supaya guru dapat membimbing dan mengarahkan siswa sehingga mampu memenuhi indikator pencapaian kompetensi siswa.

Guru dituntut memiliki kompetensi profesional, terutama pengembangan materi dari berbagai sumber belajar. Kompetensi siswa dapat dikembangkan melalui sumber belajar yang didalamnya memuat materi. Sumber belajar memiliki kontribusi yang signifikan terhadap ketersediaan berbagai informasi dan pengetahuan yang dibutuhkan untuk pengembangan kompetensi-kompetensi yang diharapkan (Jailani, 2016: 175).

Sumber belajar memiliki beberapa klasifikasi. Klasifikasi jenis sumber belajar dapat dikategorikan menjadi tempat atau lingkungan alam sekitar, benda, orang, buku, bahan, dan peristiwa (Hamdani, 2011: 119). Banyaknya macam sumber belajar ini memudahkan guru dalam memfasilitasi dan memvariasikan pemahaman siswa tentang materi pelajaran. Permendiknas Nomor 41 Tahun 2007 Tentang Standar Proses Untuk Satuan Pendidikan Dasar dan Menengah disebutkan bahwa: 
"Indikator kompetensi adalah perilaku yang dapat diukur dan/atau diobservasi untuk menunjukkan ketercapaian kompetensi dasar tertentu yang menjadi acuan penilaian mata pelajaran. Indikator pencapaian kompetensi dirumuskan dengan menggunakan kata kerja operasional yang dapat diamati dan diukur, yang mencakup pengetahuan, sikap, dan keterampilan".

Jadi, sumber belajar juga harus mempertimbangkan indikator pencapaian kompetensi siswa. Indikator pencapaian kompetensi akan menjadi acuan untuk guru dalam mengembangkan materi.

Pendidikan Pancasila dan Kewarganegaraan sendiri memiliki kajian tersendiri terhadap tiga ranah yang terdapat dalam materi pelajaran, yaitu pengetahuan kewarganegaraan (civic knowledge), keterampilan kewarganegaraan (civic skill), dan sikap kewarganegaraan (civic disposition). Civic skill terdiri atas civic intellectual skill (keterampilan intelektual warganegara) dan civic participatory skill (keterampilan partisipasi warganegara).

Kenyataan di lapangan masih terdapat guru yang bertumpu pada buku teks sebagai satu-satunya sumber materi pelajaran. Guru yang mengandalkan buku teks memiliki kecenderungan menyajikan materi pelajaran yang cenderung kurang bermanfaat bagi siswa. Sekolah dengan fasilitas yang memadai, seperti ruang kelas, buku teks, dan perpustakaan mendapatkan nilai yang lebih tinggi daripada sekolah-sekolah yang tidak memenuhi fasilitas tersebut (Ogweno, 2015: 577). Fasilitas sekolah menjadi salah satu komponen yang besar pengaruhnya terhadap kemajuan pendidikan di suatu sekolah. Kemampuan guru dalam mengelola kelas melalui sumber belajar dikelas masih belum maksimal, penyebabnya adalah keterbatasan pembaharuan berbagai jenis sumber belajar, keterbatasan skill dalam pemanfaatan sumber belajar yang relevan dengan $\mathrm{KD}$, dan keterbatasan waktu yang dibutuhkan oleh guru (Fitrah, 2015: 883).

Kajian tentang sumber belajar sudah terlebih dahulu dilakukan oleh peneliti lain, yaitu Pemanfaatan Sumber-Sumber Belajar dalam Proses Pembelajaran di SMP Negeri 2 Lebaksiu, Tegal menyebutkan bahwa usaha mengoptimalkan sumber belajar terhitung 51\% (kategori cukup baik) serta keefektifan pemanfaatan sumber belajar terhitung $48 \%$ (kategori kurang baik) (Any, 2011: 8). Perbedaan penelitian yaitu penelitian tersebut membahas mengenai pemanfaatan sumber belajar sedangkan penelitian saya membahas mengenai ketersediaan sumber belajar, relevansi sumber belajar dengan indikator pencapaian kompetensi siswa, dan kendala guru dalam pemanfaatan sumber belajar. Penelitian tentang Pemanfaatan Sumber Belajar Sejarah Siswa Untuk Mendukung Ketercapaian Pembelajaran IPS SMP SeKota Semarang (Studi Kasus SMP H. Isriati Semarang, SMP Negeri 6 Semarang dan SMP Negeri 24 Semarang) menyebutkan bahwa masing-masing guru dan siswa di tiga SMP Kota Semarang dapat memanfaatkan sumber belajar sejarah di dalam ataupun luar sekolah, hambatan yang dialami guru dalam penggunaan sumber belajar yaitu perbedaan pembahasan materi antar buku penerbit (Wahyuningtyas, 2016: 8). Kemudian, dalam pemanfaatan sumber belajar sejarah yang ada diluar sekolah membutuhkan waktu, biaya dan pengawasan yang lebih. Perbedaan penelitian yaitu penelitian tersebut fokus membahas mengenai pemanfaatan sumber belajar beserta kendalanya sedangkan penelitian saya membahas mengenai ketersediaan sumber belajar, relevansi sumber belajar dengan 
Wijianto, Muhammad Hendri Nuryadi, Siska Nurdiani -- Relevansi Sumber Belajar Ketahanan Nasional Mata Pelajaran Pendidikan Pancasila Dan Kewarganegaraan Dengan Indikator Pencapaian Kompetensi Siswa (Studi Di Sma Negeri 1 Surakarta, Jawa Tengah)

indikator pencapaian kompetensi siswa, dan kendala guru dalam pemanfaatan sumber belajar.

Di dalam jurnal ini, peneliti menjawab tiga rumusan permasalahan yaitu: Bagaimana ketersediaan sumber belajar ketahanan nasional mata pelajaran PPKn di SMA Negeri 1 Surakarta?; Bagaimana relevansi sumber belajar ketahanan nasional mata pelajaran PPKn Kelas XI dengan Indikator Pencapaian Kompetensi Siswa di SMA Negeri 1 Surakarta?; dan Bagaimana kendala guru dalam pemanfaatan sumber belajar ketahanan nasional mata pelajaran PPKn Kelas XI di SMA Negeri 1 Surakarta?.

Penelitian menggunakan pendekatan deskriptif kualitatif. Teknik pengambilan sampel, yaitu sampling purposive. Teknik pengumpulan data berupa wawancara, observasi, studi dokumen, dan angket. Wawancara terhadap kepala sekolah, wakil kepala urusan kurikulum, guru PPKn serta siswa SMA Negeri 1 Surakarta. Selain itu, observasi dilakukan dengan mengamati kegiatan belajar mengajar di kelas. Dokumen yang dianalisis adalah Rencana Pelaksanaan Pembelajaran (RPP), sumber belajar mata pelajaran PPKn kelas XI khusus KD 3.5 yang terdiri atas Buku Siswa, Lembar Kerja Siswa (LKS), dan website, serta pengembangan materi oleh guru. Kemudian, angket yang disebar pada beberapa siswa kelas XI. Angket diolah dengan analisis skor skala likert yaitu $4=$ selalu, 3 = sering, 2 = kadang-kadang, dan 1 = tidak pernah kemudian dianalisis dengan persentase. Teknik uji validitas data dalam penelitian menggunakan triangulasi metodologis dan trianggulasi data. Sumber data yang digunakan, yaitu informan guru dan siswa di SMA Negeri 1 Surakarta, dokumen terkait, tempat, dan peristiwa.

\section{PEMBAHASAN}

Ketersediaan Sumber Belajar Ketahanan Nasional Mata Pelajaran PPKn di SMA Negeri 1 Surakarta

Sumber belajar menjadi salah satu komponen utama dalam pembelajaran. Ketersediaan sumber belajar yang baik dapat memfasilitasi guru dan siswa mencapai tujuan pembelajaran. Maka, guru PPKn sebaiknya pandai memilih dan memanfaatkan sumber belajar yang relevan dengan materi pelajaran.

Ketersediaan sumber belajar juga dapat diketahui dari sumber belajar yang dijadikan pedoman guru untuk mengembangkan materi. Guru sebagai pengelola pembelajaran dituntut untuk memiliki kreatifitas dalam mengelola kelasnya, salah satunya adalah dalam pemilihan dan penggunaan sumber belajar. Guru PPKn harus pandai dalam memilah sumber-sumber belajar yang cocok untuk mengembangkan materi pelajaran. Saat memilih materi untuk mengembangkan materi pelajaran maka guru harus menyesuaikan dengan tujuan pembelajaran yang telah ditentukan.

Ketersediaan sumber belajar PPKn kelas XI, maka peneliti menyebar angket kepada beberapa siswa. Terdapat 8 pernyataan beradasarkan tigkat penggunaan sumber belajar. Tiap butir pernyataan memiliki skor 1 sampai 4, meliputi skor 4 berarti selalu, skor 3 berarti sering, skor 2 kadang-kadang, dan skor 1 berarti tidak pernah. Berikut, tabel 1 merupakan hasil angket sebagai gambaran ketersediaan sumber belajar PPKn.

Berdasarkan tabel 1 tersebut dapat dinyatakan bahwa sumber belajar ketahanan nasional mata pelajaran PPKn yang selalu digunakan oleh siswa kelas XI di SMA Negeri 1 Surakarta adalah buku sebanyak 62,5\%. Sumber belajar lain berupa bahan 32,5\%, peristiwa $25 \%$, benda $15 \%$, dan tempat 
Tabel 1

Tabulasi Persentase Guru dan Siswa dalam Menggunakan Sumber Belajar PPKn Kelas XI di SMA Negeri 1 Surakarta

\begin{tabular}{llcccc}
\hline \multirow{2}{*}{ No. } & \multicolumn{1}{c}{ Pernyataan } & Selalu & Sering $\begin{array}{c}\text { Kadang- } \\
\text { Kadang }\end{array}$ & $\begin{array}{c}\text { Tidak } \\
\text { Pernah }\end{array}$ \\
\cline { 3 - 6 } & & & & $\%$ & \\
\hline 1. & Buku & 62,5 & 37,5 & 0 & 0 \\
\hline 2. & Bahan (teks tertulis, rekaman, film, video, website, dll) & 32,5 & 60 & 7,5 & 0 \\
\hline 3. & Tempat (perpustakaan, pasar, dan museum, dll) & 7,5 & 52,5 & 37,5 & 2,5 \\
\hline 4. & Orang (hakim, polisi, dan ahli-ahli lainnya) & 10 & 57,5 & 32,5 & 0 \\
\hline 5. & Benda (situs, candi, benda peninggalan, dll) & 15 & 45 & 40 & 0 \\
\hline 6. & $\begin{array}{l}\text { Peristiwa (peristiwa kerusuhan, peristiwa bencana, dan } \\
\text { peristiwa lainnya) }\end{array}$ & 25 & 67,5 & 5 & 2,5 \\
\hline
\end{tabular}

Sumber: Dokumen Peneliti, 2019

7,5\%. Hal ini menunjukkan jika penggunaan sumber belajar berupa buku paling dominan dibandingkan dengan sumber belajar lainnya.

Data tentang ketersediaan sumber belajar ini juga ditunjang dengan koleksi pustaka di perpustakaan SMA Negeri 1 Surakarta. Berikut, tabel 2 merupakan koleksi perpustakaan yang berkaitan dengan PPKn di SMA Negeri 1 Surakarta.

Tabel 2

Rincian Koleksi Perpustakaan SMA Negeri 1 Surakarta

\begin{tabular}{clcc}
\hline No. & Jenis Koleksi & $\begin{array}{c}\text { Jumlah } \\
\text { Eksemplar }\end{array}$ & Presentase \\
\hline 1. & Buku & 30 & 7,11 \\
\hline 2. & Majalah & 0 & 0 \\
\hline 3. & Klipping & 0 & 0 \\
\hline 4. & Karya Tulis & 0 & 0 \\
\hline 5. & Penelitian & 0 & 0 \\
\hline 6. & Buku Paket & 385 & $91,23 \%$ \\
\hline 7. & Bank Soal Reguler & 0 & 0 \\
\hline 8. & Buku Referensi & 7 & $1,66 \%$ \\
\hline 9. & Fiksi & 0 & 0 \\
\hline 10. & DVD/CD & 0 & 0 \\
\hline
\end{tabular}

Sumber: Dokumen SMA Negeri 1 Surakarta Tahun 2018/2019

Berdasarkan tabel 2 tersebut dapat ditunjukkan bahwa koleksi perpustakaan SMA Negeri 1 Surakarta, khususnya yang mendukung mata pelajaran PPKn didominasi sumber belajar berupa buku. Koleksi yang paling mendominasi adalah buku paket PPKn kelas XI yaitu sebanyak 385 eksemplar atau 91,23\% dari jumlah keseluruhan jenis koleksi. Kemudian, buku sebanyak 30 eksemplar atau 7,11\% dari jumlah keseluruhan jenis koleksi, dan buku referensi sebanyak 7 eksemplar atau $1,66 \%$ dari jumlah keseluruhan jenis koleksi. Data ini menunjukkan jika sumber belajar masih terpaku pada buku paket sedangkan buku pendukung yang dijadikan sebagai referensi mata pelajaran PPKn masih terbatas jumlahnya.

Penelitian ini juga melakukan observasi pada saat pembelajaran PPKn yang dilaksanakan guru di kelas. Ketika pembelajaran berlangsung, guru dan siswa menggunakan sumber belajar berupa satu eksemplar LKS dan satu eksemplar Buku Siswa. Selanjutnya ketika guru menerangkan materi pelajaran kepada siswa, guru menambahkan materi dari website. Berdasarkan hasil pengamatan dapat diketahui ketersediaan sumber belajar PPKn kelas XI di SMA Negeri 1 Surakarta yaitu LKS dan Buku Siswa. Guru juga menggunakan website untuk mengembangkan materi saat mencari contoh ancaman terhadap NKRI.

Selain wawancara dan observasi, penelitian ini juga melakukan analisis 
Wijianto, Muhammad Hendri Nuryadi, Siska Nurdiani -- Relevansi Sumber Belajar Ketahanan Nasional Mata Pelajaran Pendidikan Pancasila Dan Kewarganegaraan Dengan Indikator Pencapaian Kompetensi Siswa

(Studi Di Sma Negeri 1 Surakarta, Jawa Tengah)

dokumen terhadap Rencana Pelaksanaan Pembelajaran yang dibuat oleh guru. Dalam rangka mengetahui sumber belajar yang digunakan, peneliti fokus pada sumber belajar yang tertulis di RPP tersebut. Menurut RPP yang dibuat guru ketika akan mengajar, dapat diketahui bahwa sumber belajar yang dimanfaatkan adalah LKS, Buku Guru, Buku Siswa dan website. Namun, Buku Guru di sini tidak digunakan sebagai sumber belajar yang bersifat bahan ajar. Buku Guru ini hanya menjadi acuan guru PPKn dalam merancang pembelajaran.

Ketersediaan sumber belajar PPKn kelas XI di SMA Negeri 1 Surakarta cukup memadai karena yang tersedia hanya buku yang terdiri dari LKS dan Buku Siswa, serta bahan yang berupa website saat mencari materi tentang contoh ancaman terhadap NKRI di https:// id.wikipedia.org/wiki/Ancaman_nonmiliter dan https://id.wikipedia.org/wiki/Ancaman militer. Koleksi perpustakaan pun masih didominasi buku paket sedangkan buku pendukung yang dijadikan yang dijadikan sebagai referensi mata pelajaran PPKn masih terbatas jumlahnya.

Sumber belajar memiliki peranan penting dalam proses, seperti dinyatakan Fentim bahwa "teachers acknowledged the importance of teaching and learning resources in schools. Majority of them agreed that teaching and learning resources help to facilitate students 'understanding of lessons" (Fentim, 2014: 85). Melihat kenyataan yang ada di sekolah, sumber belajar masih minim dalam hal variasi dan jumlahnya. Sedangkan sumber dapat dikategorikan sebagai berikut: (1). Tempat yaitu dimana saja seseorang dapat melakukan belajar atau proses perubahan tingkah laku, misalnya perpustakaan, pasar, dan museum; (2). Benda yaitu segala benda yang memungkinkan terjadinya perubahan tingkah laku bagi siswa, misalnya situs, candi, benda peninggalan lainnya; (3). Orang yaitu siapa saja yang memiliki keahlian tertentu yang bisa mengajarkan sesuatu kepada siswa, misalnya dokter, polisi, dan ahliahli lainnya; (4). Buku yaitu segala macam buku yang dapat dimanfaatkan oleh siswa, misalnya buku pelajaran, buku teks, kamus, ensiklopedi, fiksi dan lain sebagainya; (5). Bahan, yaitu segala sesuatu yang berupa teks tertulis, cetak, rekaman, elektronik, website yang dapat dimanfaatkan untuk belajar; (6). Peristiwa dan fakta yang sedang terjadi, guru dapat menjadikan peristiwa dan fakta sebagai sumber belajar, misalnya peristiwa kerusuhan, peristiwa bencana dan peristiwa lainnya (Hamdani, 2011: 120).

Sumber belajar tersebut menurut Association for Education and Communication Technology termasuk dalam sumber belajar yang dirancang (resources by design), yaitu semua sumber yang secara khusus telah dikembangkan sebagai komponen sistem pembelajaran untuk memberikan fasilitas belajar yang terarah, dan bersifat formal, misalnya: buku paket, modul, lembar kerja siswa (LKS) (Anitah, 2009: 126-127).

Dalam PPKn mencari dan menentukan sumber belajar merupakan hal sangat penting, karena bahan ajar PPKn sangat dinamis sesuai dinamika dan perkembangan kehidupan sosial politik yang terjadi saat ini (Sapriya, 2012: 195). Maka, sumber belajar PPKn tidak hanya dari buku teks atau buku paket saja. Melainkan memanfaatkan sumber belajar dari media cetak maupun media elektronik dan manusia baik tokoh masyarakat atau pakar di bidang tertentu. Hasil penelitian ini memperkuat penelitian yang dilakukan oleh Abdullah (2012) tentang "pembelajaran 
berbasis pemanfaatan sumber belajar", yang menyatakan bahwa bahwa sumber belajar yang dapat dimanfaatkan untuk kebutuhan pembelajaran sangat beragam jenis dan bentuknya, sumber belajar tersebut bukan hanya dalam bentuk bahan cetakan seperti buku teks akan tetapi pelajar dapat memanfaatkan sumber belajar yang lain seperti radio, komputer, e-mail, vidio interaktif, dan lain-lain.

\section{Relevansi Sumber Belajar Ketahanan Nasional Mata Pelajaran PPKn Kelas XI Di SMAN I Dengan Indikator Pencapaian Kompetensi Siswa}

Relevansi ini merujuk pada tingkat kesesuaian sumber belajar dengan indikator pencapaian kompetensi siswa yang telah ditetapkan. Jadi, sebaiknya guru harus memahami kesesuaian sumber belajar dengan indikator pencapaian kompetensi siswa yang ingin diraih. Hal ini dilakukan supaya siswa mendapatkan sumber belajar yang tepat untuk mendukung kegiatan pembelajaran. Jika dihubungkan dengan Teori Belajar Bermakna David Ausubel bahwa bahan ajar akan lebih mudah dipahami jika bahan ajar dirasa bermakna bagi peserta didik (Kurniasih, 2014: 15-16). Dengan demikian, sumber belajar yang digunakan harus memuat keterkaitan seluruh bahan agar sesuai dengan struktur kognitf dan struktur keilmuan.

Ketika kegiatan pembelajaran, guru merumuskan indikator pencapaian kompetensi siswa yang mencakup tiga aspek yaitu, sikap, pengetahuan, dan keterampilan. PPKn sendiri memiliki kajian tersendiri pada tiga ranah tersebut, yaitu civic knowledge (pengetahuan kewarganegaraan), civic disposition (karakter privat dan karakter publik dari warga negara), dan civic skill (keterampilan warganegara yang terdiri atas keterampilan intelektual dan keterampilan partisipasi).

Penelitian ini menguji relevansi sumber belajar ketahanan nasional mata pelajaran PPKn kelas XI dengan indikator pencapaian kompetensi siswa di SMA Negeri 1 Surakarta, khususnya pada materi Mewaspadai Ancaman Terhadap NKRI. Materi ini menjadi pokok bahasan kedua PPKn yang diberikan pada siswa SMA khususnya kelas XI semester 2 berdasarkan kurikulum 2013 revisi. Materi ini juga mendukung upaya bela negara melalui pemahaman yang bersifat akademik di persekolahan. Adapun sumber belajar yang diteliti adalah Buku Siswa, LKS, dan website. Peneliti meneliti sumber belajar tersebut karena paling sering digunakan oleh guru dan siswa untuk kegiatan pembelajaran.

Melalui metode analisis dokumen dilakukan penilaian terhadap materi pada sumber belajar PPKn untuk mengukur relevansi sumber belajar dengan indikator pencapaian kompetensi siswa. Ada 8 butir pernyataan beradasarkan indikator pencapaian kompetensi siswa, yaitu cakupan materi; kedalaman materi; keluasan materi; ketetapan fakta; ketetapan konsep; ketetapan prinsip; ketepatan prosedur; dan kebenaran nilai. Tiap butir pernyataan memiliki skor 1 sampai 4, meliputi skor 4 berarti sangat baik, skor 3 berarti cukup baik, skor 2 berarti kurang baik, dan skor 1 berarti sangat tidak baik. Nilainya diambil dari skor perolehan dibagi skor maksimal dikali 100 .

Berdasarkan penilaian yang diberikan disimpulkan bahwa materi Mewaspadai Ancaman Terhadap NKRI pada Buku Siswa belum sepenuhnya relevan dengan indikator pencapaian kompetensi siswa. Buku Siswa tersebut secara keseluruhan komponen memiliki skor 73,43 yang berarti termasuk 
Wijianto, Muhammad Hendri Nuryadi, Siska Nurdiani -- Relevansi Sumber Belajar Ketahanan Nasional Mata Pelajaran Pendidikan Pancasila Dan Kewarganegaraan Dengan Indikator Pencapaian Kompetensi Siswa

(Studi Di Sma Negeri 1 Surakarta, Jawa Tengah)

kategori baik. Penilaian yang diberikan dapat disimpulkan bahwa materi Mewaspadai Ancaman Terhadap NKRI dalam LKS belum sepenuhnya sesuai dengan indikator pencapaian kompetensi siswa. LKS tersebut secara keseluruhan komponen memiliki skor 68,75 yang berarti termasuk kategori cukup. Penilaian yang diberikan dapat disimpulkan bahwa materi Mewaspadai Ancaman Terhadap NKRI, khususnya contoh ancaman terhadap NKRI di bidang militer dan non militer dalam website belum sepenuhnya sesuai dengan indikator pencapaian kompetensi siswa. Website tersebut secara keseluruhan komponen memiliki skor 65,62 yang berarti termasuk kategori cukup.

Materi Mewaspadai Ancaman Terhadap Negara Kesatuan Republik Indonesia pada sumber belajar PPKn kelas XI di SMA Negeri 1 Surakarta yang berupa Buku Siswa, LKS, dan website belum sepenuhnya memenuhi indikator pencapaian kompetensi siswa (IPK) karena karena materi yang ada hanya menyajikan civic knowledge dan civic disposition, sementara civic skillnya belum disajikan secara utuh karena hanya terpenuhi intellectual skills sedangkan komponen participatory skills belum tercapai. Penjabarannya sebagai berikut.

Pertama, civic knowledge (pengetahuan kewarganegaraan) ditunjukkan pada sub bab"Menelaah Ancaman Integrasi Nasional, Ancaman di Bidang Ideologi, Politik, Ekonomi, Sosial Budaya, Pertahanan dan Kemanan karena sudah mencakup pengetahuan kewarganegaraan tentang materi yang berkaitan dengan Mewaspadai Ancaman Terhadap NKRI. Kemudian, civic knowledge (pengetahuan kewarganegaraan) ditunjukkan pada pengembangan materi dari website, yaitu mengenai contoh ancaman terhadap NKRI di bidang militer dan non militer, karena materi tersebut berisi contoh yang bersifat pengetahuan.

Kedua, civic disposition (watak kewarganegaraan) ditunjukkan pada sub bab Strategi Mengatasi Ancaman di Bidang Ideologi dan Politik. Sub bab Strategi Mengatasi Ancaman di Bidang Ideologi dan Politik mengandung nilai-nilai yang harus dimiliki oleh warga negara seperti kejujuran, tanggung jawab, kepentingan yang sama, keadilan, solidaritas, kerjasama, dan sadar hukum.

Ketiga, civic skill (keterampilan kewarganegaraan) ditunjukkan pada sub bab Strategi Mengatasi Ancaman di Bidang Pertahanan dan Keamanan. Tetapi, pembahasan materi tersebut belum menunjukkan peran serta siswa secara konkrit atau dapat dikatakan baru memenuhi komponen intellectual skills sedangkan komponen participatory skillnya belum tercapai.

Berdasarkan penjabaran mengenai analisis materi yang terdapat pada sumber belajar PPKn kelas XI di SMA Negeri 1 Surakarta yaitu pada Buku Siswa, LKS, dan website dapat diketahui bahwa materi Mewaspadai Ancaman Terhadap NKRI hanya menyajikan civic knowledge dan civic disposition, sedangkan civic skillnya belum tersaji secara utuh karena baru memenuhi komponen intellectual skills sementara komponen participatory skills belum tercapai. Komponen civic knowledge, civic disposition dan civic inttelectual skills telah memenuhi standar kelayakan, sementara komponen participatory skills masih membutuhkan perbaikan.

Penelitian ini juga menggunakan lembar pengamatan untuk menganalisis materi yang diberikan guru ketika pembelajaran PPKn 
Wijianto, Muhammad Hendri Nuryadi, Siska Nurdiani -- Relevansi Sumber Belajar Ketahanan Nasional Mata Pelajaran Pendidikan Pancasila Dan Kewarganegaraan Dengan Indikator Pencapaian Kompetensi Siswa (Studi Di Sma Negeri 1 Surakarta, Jawa Tengah)

ideologi, politik, ekonomi, sosial budaya, dan hankam dan strategi mengatasinya dalam bingkai Bhinneka Tunggal Ika, dapat dilihat pada tabel 5 .

Tabel 5

Penilaian Rencana Pelaksanaan Pembelajaran (RPP) kelas XI di SMA Negeri 1 Surakarta

\begin{tabular}{|c|c|c|c|c|c|}
\hline \multirow{2}{*}{ No. } & \multirow{2}{*}{ Pemilihan Sumber belajar } & \multicolumn{4}{|c|}{ Skor } \\
\hline & & 1 & 2 & 3 & 4 \\
\hline 1. & $\begin{array}{l}\text { Kesesuaian dengan tujuan } \\
\text { pembelajaran }\end{array}$ & & $\sqrt{ }$ & & \\
\hline 2. & $\begin{array}{l}\text { Kesesuaian dengan materi } \\
\text { pembelajaran }\end{array}$ & & $\sqrt{ }$ & & \\
\hline
\end{tabular}

Sumber: Dokumen Peneliti, 2019

Catatan:

Skor $4=$ sangat baik

Skor 3 = baik

Skor 2 = cukup

Skor $1=$ kurang

Berdasarkan tabel 5 dapat diketahui bahwa, sumber belajar yang dijadikan guru dalam menyusun materi Mewaspadai Ancaman Terhadap NKRI yang terdapat di RPP yakni Buku Siswa, LKS, dan website pada internet diberi skor 2 artinya cukup karena belum sesuai dengan tujuan pembelajaran. Tujuan pembelajaran yang tercapai hanya dominan pada aspek pengetahuan dan aspek sikap, sedangkan untuk aspek keterampilannya belum sepenuhnya tercapai. Kemudian, kesesuaian sumber belajar dengan materi diberi skor 2 artinya cukup karena sumber belajar yang digunakan belum memenuhi materi yang sudah ditentukan dalam kompetensi dasar 3.5 tersebut. Pada sumber belajar yang memuat materi mengenai Mewaspadai Ancaman Terhadap NKRI dalam bidang ideologi, politik, ekonomi, sosial budaya, dan pertahanan keamanan serta strategi mengatasinya hanya memuat aspek pengetahuan dan sikap, sementara untuk keterampilannya belum sepenuhnya tercapai.
Materi yang terdapat pada sumber belajar PPKn kelas XI di SMA Negeri 1 Surakarta lebih banyak mengandung konsep yang berupa hafalan. Materi-materi PPKn yang diajarkan cenderung berbentuk hafalan atau kognitif. Poblem sesungguhnya yang dihadapi mata pelajaran PPKn lebih banyak karena kejenuhan terhadap materi yang diajarkan cenderung monoton, teoretik, kognitif, bahkan verbalistik (Haryati, 2018: 352). Jadi, pengembangan komponen kompetensi kewarganegaraan sebagian besar masih berorientasi pada penguatan komponen pengetahuan kewarganegaraan.

Padahal, diperlukan kajian isu aktual ketahanan nasional untuk mendukung isi pendidikan kewarganegaraan persekolahan sebagai dasar perumusan indikatorindikator pembelajaran (Branson, 1998). Materi harusnya lengkap memuat ketiga ranah tersebut sebab ada tiga kompetensi utama dalam Pendidikan Pancasila dan Kewarganegaraan, senada menurut Branson (1998), yaitu What are essential components of a good civic education? There are three essential components: civic knowledge, civic skills, and civic disposition. Maka, sebaiknya materi pelajaran memuat ketiga komponen tersebut.

\section{Kendala yang Dialami Guru}

Kendala dalam pemanfaatan sumber belajar disini adalah sulit tidaknya sumber belajar digunakan, baik secara teknis penggunaannya dan kualitasnya. Sebaiknya guru memilih sumber belajar yang mudah digunakan dalam penggunaanya dan berkualitas secara isi supaya sumber belajar tersebut mampu membantu siswa menguasai kompetensi. Namun, pada kenyataannya dalam pemanfaatan sumber belajar PPKn 
kelas XI di SMA Negeri 1 Surakarta masih terdapat beberapa kendala.

Selanjutnya penelitian ini juga melakukan observasi untuk memperkuat informasi mengenai kendala guru dan siswa dalam pemanfaatan sumber belajar PPKn kelas XI di SMA Negeri 1 Surakarta. Berdasarkan hasil observasi ditemukan bahwa semua siswa menggunakan sumber belajar Buku Siswa dan LKS secara teknis mudah digunakan, namun tingkat keluasan materinya kurang. Ketika materi di Buku Siswa dan LKS tidak lengkap, maka dilengkapi dari internet. Namun, internet juga terkendala di siyal wifi dan terdapat beberapa informasi yang tidak valid sehingga harus cross check lagi ke gurunya langsung.

Penelitian ini juga mengambil data dari angket yang disebar ke beberapa siswa untuk mengetahui kendala dalam pemanfataan sumber belajar PPKn kelas XI di SMA Negeri 1 Surakarta. Berikut, tabel 6 merupakan hasil angket sebagai gambaran kendala dalam pemanfataan sumber belajar PPKn kelas XI di SMA Negeri 1 Surakarta.

Berdasarkan tabel 6 diketahui, bahwa beberapa siswa mengalami kendala dalam pemanfaatan sumber belajar PPKn kelas XI di SMA Negeri 1 Surakarta karena masih ada 20\% siswa yang kadang-kadang kesulitan dalam pemanfaatan sumber belajar dan sebanyak 5\% siswa merasa kesulitan dalam pemanfaatan sumber belajar. Kemudian, sumber belajar yang tersedia kadang-kadang mudah digunakan dengan presentase 12,5\% dan sumber belajar yang digunakan kadangkadang membutuhkan persiapan/skill khusus sebanyak $17,5 \%$. Hal ini menunjukkan sumber belajar PPKn kelas XI terdapat kendala dalam pemanfaatannya.

Selain itu, penelitian ini juga melakukan analisis pada dokumen foto-foto pembelajaran PPKn yang dilaksanakan guru di kelas. Berdasarkan hasil dari analisis dokumen tersebut diperoleh informasi bahwa sumber belajar pada saat pembelajaran PPKn secara teknis mudah digunakan, hanya saja terkendala pada ketidaklengkapan materi.

Kendala yang dialami guru dalam pemanfaatan sumber belajar PPKn kelas XI di SMA Negeri 1 Surakarta, sebagai berikut.

Pertama, kendala guru dalam pemanfaatan Buku Siswa dan LKS. Kendala guru dalam pemanfaatan sumber belajar berupa buku yaitu Buku Siswa dan LKS adalah terdapat materi yang keliru dan keluasan materinya pun masih kurang. Keluasan materi yang kurang ini disebabkan karena materi pada kurikulum 2013 lebih dipersempit tetapi lebih diperdalam sehingga sampai pada tingkatan berpikir create atau mencipta, sedangkan materi di kurikulum sebelumnya atau KTSP itu luas sekali, tapi hanya sampai pemahaman. Guru harus menambahkan pengayaan yang cukup untuk menutupi kekurangan materinya

Tabel 6

Tabulasi Persentase Kendala Dalam Pemanfataan Sumber Belajar PPKn kelas XI di SMA Negeri 1 Surakarta

\begin{tabular}{|c|c|c|c|c|c|}
\hline \multirow{2}{*}{ No. } & \multirow{2}{*}{ Pernyataan } & Selalu & Sering & Kadang-Kadang & Tidak Pernah \\
\hline & & \multicolumn{4}{|c|}{$\%$} \\
\hline & $\begin{array}{l}\text { Saya tidak mengalami kesulitan dalam pemanfaatan } \\
\text { sumber belajar PPKn }\end{array}$ & 20 & 55 & 20 & 5 \\
\hline 2. & Sumber belajar yang tersedia mudah digunakan & 12,5 & 75 & 12,5 & 0 \\
\hline 3. & $\begin{array}{l}\text { Sumber belajar yang digunakan tidak membutuhkan } \\
\text { persiapan/skill khusus }\end{array}$ & 15 & 67,5 & 17,5 & 0 \\
\hline
\end{tabular}

Sumber: Dokumen Peneliti, 2019 
Wijianto, Muhammad Hendri Nuryadi, Siska Nurdiani -- Relevansi Sumber Belajar Ketahanan Nasional Mata Pelajaran Pendidikan Pancasila Dan Kewarganegaraan Dengan Indikator Pencapaian Kompetensi Siswa

(Studi Di Sma Negeri 1 Surakarta, Jawa Tengah)

karena di soal ujian nasional pun masih muncul materi yang ada di KTSP.

Kedua, kendala guru dalam pemanfaatan website. Kendala guru dalam pemanfaatan sumber belajar bahan berupa website yang diakses di internet adalah tidak stabilnya sinyal wifi di sekolah dan beberapa website memuat informasi yang tidak valid.

Apa yang dialami oleh guru tersebut kiranya sesuai dengan temuan hasil penelitian yang dilakukan oleh Aini (2017) tentang "studi analisis pemanfaatan sumber belajar sejarah di SMA N 1 JEPARA dan SMA N 1 BANGSRI kelas $\mathrm{x}$ semester genap tahun pelajaran 2016/2017 dalam kurikulum 2013" yang menyatakan bahwa "kendala yang dihadapi guru sejarah dalam pemanfaatan sumber belajar sejarah ini meliputi kendala internal yang berupa perbedaan kualitas dan kemampuan yang dimiliki oleh masing-masing guru dalam setiap sekolah dan kendala eksternal yaitu perbedaan sarana prasarana di masing-masing sekolah yang dalam pemenuhan kebutuhan sumber belajar". Kendala-kendala tersebut dialami oleh guru dalam proses pemanfaatan sumber belajar, baik secara kualitas materi karena bagi guru, sebetulnya diperlukan keahlian pengembangan materi, serta kendala dari berbagai fasilitas atau sarana dan prasarana yang belum menunjang proses pemanfaatan sumber belajar.

Sumber belajar tempat, seperti perpustakaan belum dimanfaatkan secara maksimal sebab buku-buku yang ada tidak lengkap. Sedangkan sumber belajar benda, seperti benda peninggalan belum memanfaatkan sebab ada kendala di waktu dan anggaran, begitupun orang, contohnya mendatangkan polisi, TNI. Sumber belajar berupa peristiwa, misalnya peristiwa kerusuhan juga belum memanfaatkan karena terkendala waktu dan biaya.
Ketiga sumber belajar tersebut secara teknis mudah dalam pengoperasiannya karena tidak membutuhkan persiapan atau skill khusus tertentu seperti kemampuan Teknologi Informasi dan Komunikasi. Jika sumber belajar memerlukan persiapan dan skill khusus, persiapan yang lama, serta memerlukan perangkat pendukung lain yang rumit, dan kita sendiri tidak mampu mengoperasionalkannya, sebaiknya sumber belajar tersebut tidak digunakan (Prastowo, 2014: 355).

Beberapa permasalahan tersebut menjelaskan adanya kendala yang dialami dalam pemanfaatan sumber belajar ketahanan nasional, hal ini dikarenakan materi ketahanan nasional di KTSP masih dalam konteks menjelaskan konsep-konsep atau pengertian teori, sedangkan di Kurikulum 2013 dibutuhkan analisis yang lebih mendalam dan studi-studi kasus kontemporer sehingga siswa dapat diarahkan untuk bersikap pada suatu fenomena. sedangkan pada website terkendala pada sinyal wifi dan terdapat informasi yang tidak dapat dipertanggungjawabkan kebenarannya. Terkait dengan pemanfaatan sumber belajar, pada prinsipnya proses pemanfaatannya itu juga sangat penting, sehingga kendala perlu dianalisis dan memerlukan proses dialog yang efektif dalam proses pembelajaran. Calcagni \& Lago. (2018) melakukan penelitian tentang "The Three Domains for Dialogue: A framework for analysing dialogic approaches to teaching and learning" yang memaparkan bahwa ada setidaknya tiga domain untuk berdialog dalam proses pembelajaran, yaitu dalam teaching larning (proses pembelajaran), domain assumpsion (asumsi), dan domain discussion (diskusi). ketiga domain ini saling berkaitan, dan dalam domain proses pembelajaran terdapat aspek pemanfaatan 
sumber-sumber belajar yang perlu diperdalam dan dianalisis secara progresif sebelum kemudian disampaikan kepada peserta didik. Hal ini menunjukkan bahwa analisis pemanfaatan sumber belajar sangat penting dilakukan dalam sebuah proses pembelajaran.

\section{SIMPULAN}

Berdasar uraian-uraian tersebut di atas dapat ditarik simpulan sebagai berikut.

Pertama, ketersediaan sumber belajar ketahanan nasional mata pelajaran Pendidikan Pancasila dan Kewarganegaraan kelas XI di SMANegeri I Surakarta cukup memadai sebab hanya tersedia buku berupa Buku Siswa, LKS, dan bahan berupa website sebagai sumber untuk mencari materi tentang contoh ancaman terhadap NKRI. Koleksi perpustakaan pun masih didominasi buku paket sedangkan buku pendukung yang dijadikan yang dijadikan sebagai referensi mata pelajaran PPKn masih terbatas jumlahnya.

Kedua, materi mata pelajaran Mewaspadai Ancaman terhadap NKRI yang terdapat pada sumber belajar ketahanan nasional mata pelajaran PPKn kelas XI di SMA Negeri I Surakarta berupa Buku Siswa, LKS, dan website belum memenuhi indikator pencapaian kompetensi siswa sebab materi yang ada baru menyajikan civic knowledge dan civic disposition, sementara civic skillnya belum sepenuhnya tersaji karena baru memenuhi komponen intellectual skills sementara komponen participatory skills belum tercapai.

Ketiga, kendala yang dialami guru dalam pemanfaatan sumber belajar ketahanan nasional mata pelajaran PPKn kelas XI di SMA Negeri I Surakarta untuk Buku Siswa dan LKS, yaitu terdapat materi yang keliru dan keluasan materinya pun masih kurang. Keluasan materi yang kurang ini disebabkan karena materi pada kurikulum 2013 lebih dipersempit tetapi lebih diperdalam sehingga sampai pada tingkatan berpikir create atau mencipta, sedangkan materi di kurikulum sebelumnya atau KTSP lingkup materinya lebih luas, tetapi hanya sampai tahap penjelasan dan pemahaman saja atau dalam konteks hafalan. Guru harus menambahkan pengayaan yang cukup untuk menutupi kekurangan materinya karena di soal ujian nasional pun masih muncul materi yang ada di KTSP. Penggunaan website lewat internet juga terkendala di sinyal wifi dan beberapa memuat informasi yang tidak valid.

\section{DAFTAR PUSTAKA}

Abdullah, R., 2012, Pembelajaran Berbasis Pemanfaatan Sumber Belajar, Jurnal Ilmiah DIDAKTIKA, vol. 1, no. 2, hh. 216-231, diperoleh 30 Januari 2019 dari HYPERLINK. https://media. neliti.com/media/publications/81198ID-pembelajaran-berbasis-pemanfaatansumber.pdf

Agus, A. Aco, 2015, Urgensi Ketahanan Nasional sebagai Geostrategi Indonesia, Jurnal Integrasi PIPS Pascasarjana UNM, vol. 1, no. 2, hh. 247-257, diperoleh 30 September 2019 dari http:// eprints.unm.ac.id/2692/.

Aini, N. 2017. Studi Analisis Pemanfaatan Sumber Belajar Sejarah di SMA N 1 JEPARA dan SMAN 1 BANGSRI Kelas X Semester Genap Tahun Pelajaran 2016/2017 dalam Kurikulum 2013. Repository Unnes: https://lib.unnes. ac.id/30066/1/3101413097.pdf

Anitah, S. 2009, Teknologi Pembelajaran, Surakarta: Yuma Pustaka, hh. 126-127. Any, J. I., 2011, Pemanfaatan Sumber-sumber Belajar dalam Proses Pembelajaran di 
Wijianto, Muhammad Hendri Nuryadi, Siska Nurdiani -- Relevansi Sumber Belajar Ketahanan Nasional Mata Pelajaran Pendidikan Pancasila Dan Kewarganegaraan Dengan Indikator Pencapaian Kompetensi Siswa

(Studi Di Sma Negeri 1 Surakarta, Jawa Tengah)

SMP Negeri 2 Lebaksitu Kabupaten Tegal. Skripsi, hh. 8, diperoleh 5 Januari 2019 dari https://lib.unnes.ac.id/7734/.

Branson, M. S., 1998, The Role of Civic Education, Calabasa: CCE, diperoleh 5 Januari 2019 dari dari http://www. civiced.org/papers/articles_role.html.

Calcagni, E \& L. Lago, 2018. "The Three Domains for Dialogue: A framework for analysing dialogic approaches to teaching and learning", Journal Learning, Culture and Social Interaction 18 (2018) $\mathrm{pp}$. $1-12$

Fentim, D. B., 2014, An Investigation On Teaching And Learning Resources/ Materials Used In Financial Accounting Lessons In Shs In Sunyani Municipality, International Journal of Research In Social Science, vol. 4, no. 2, hh. 84-92, diperoleh 5 Februari 2019 dari http:// ijsk.org/uploads/3/1/1/7/3117743/11 teaching_and_learning_resources.pdf.

Fitrah, M., Kemampuan Guru Matematika Dalam Mengelola Kelas Melalui Sumber Belajar Untuk Meningkatkan Aktivitas Siswa, Prosiding Seminar Nasional Matematika, 2015, hh. 883890, diperoleh 30 Januari 2019 dari file:///C:/Users/asus/Downloads/ ProsidingSemnastika2015_UNESA.pdf. Hamdani, 2011, Strategi Belajar Mengajar, Bandung: CV. Pustaka Setia.

Haryati, Sri dan Wijianto, 2018, Konstruksi Isu Aktual Bidang Ketahanan Nasional Untuk Pengembangan Isi Pendidikan Kewarganegaraan Persekolahan, Jurnal Ketahanan Nasional, vol. 24, no. 3, hh. 342-353, diperoleh 30 September 2019 dari http://jurnal.ugm.ac.id/JKN.

Jailani, M. S., 2016, Pengembangan Sumber Belajar Berbasis Karakter Peserta
Didik, Jurnal Pendidikan Islam, vol. 10, no. 2, hh. 175-192, diperoleh 30 Januari 2019 dari file:///C:/Users/asus/ Downloads/1284-2779-1-PB\%20(1). $p d f$.

Julaikah, I., 2017, Problematika Guru dalam Peningkatan Kompetensi Di SD Negeri 1 Simo, Publikasi Ilmiah, hh. 1-8, diperoleh 30 Januari 2019 dari http:// eprints.ums.ac.id/51220/1/01.\%20 PUBLIKASI\%20ILMIAH.pdf

Juniantari, I. G., 2017, Pentingnya Peningkatan Kompetensi Guru Dalam Pencapaian Hasil Belajar Siswa, Article Research Gate, hh. 1-12, diperoleh 30 Januari 2019 darifile:///C:/Users/asus/Downloads/19. IGustiAyuSriJuniantari_Artikel.pdf

Kartowagiran, 2011, Kinerja Guru Profesional (Guru Pasca Sertifikasi), Jurnal Cakrawala Pendidikan, vol. 30, no. 3, hh. 463-473, diperoleh 30 Januari 2019 dari https://media.neliti.com/media/ publications/76334-ID-kinerja-guruprofesional-guru-pasca-sert.pdf.

Kurniasih, S., 2014, Strategi-Strategi Pembelajaran, Bandung: Alfabeta.

Mulyasa, 2013, Uji Kompetensi dan Penilaian Kinerja Guru, Bandung: PT. Remaja Rosdakarya.

Ogweno, P. O., 2015, Teaching and Learning Resources as Determinants of Students Academic Performance in Secondary Agriculture, in Rachuonyo North Sub County, Kenya, International Journal of Advanced Research, vol. 3, no. 9, hh. 577-587, diperoleh 18 Januari 2019 dari http://www.journalijar.com/ uploads/634_IJAR-7034.pdf.

Permata, Rima Vien dan Anita Trisiana, 2012, Implementasi Model Pembelajaran Pilot Project Citizen Berbasis Nasionalisme 
Pada Pendidikan Kewarganegaraan Demi Mewujudkan Karakter Peserta Didik, Jurnal Ketahanan Nasional, vol. 18 , no. 3 , hh. 1-22, diperoleh 30 September 2019 dari http://jurnal.ugm. ac.id/JKN.

Prastowo, A., 2014, Pengembangan Bahan Ajar Tematik: Tinjauan Teoritis dan Praktik. Jakarta: Kencana Prenadamedia Group.

Sapriya, 2012, Pembelajaran Pendidikan Kewarganegaraan (PKn), Jakarta: Direktoral Jenderal Pendidikan Dasar dan Menengah.

Ushani, D., 2017, Indikator Guru Inpiratif dan Profesional, Artikel Research Gate, hh. 1-11, diperoleh 30 Januari 2019 dari file://C:/Users/asus/Downloads/ ARTIKELSEMINARdesaknew.pdf.

Wahyuningtyas, P. F., Pemanfaatan Sumber Belajar Sejarah Siswa untuk Mendukung Ketercapaian Pembelajaran IPS SMP Se-Kota Semarang (Studi Kasus SMP H. Isriati Semarang, SMP N 6 Semarang dan SMP N 24 Semarang) Tahun Pelajaran 2015/2016, Skripsi, 2016, hh. 8, diperoleh dari https://lib.unnes.ac.id/27057/
Winarno, 2013, Strategi Penanaman Ideologi Pancasila Sebagai Solusi Terkikisnya Nasionalisme Melalui Pengembangan Model Pembelajaran Berorientasi Kompetensi Pendidikan Kewarganegaraan Perguruan Tinggi, Jurnal Ketahanan Nasional, vol. 19, no.2, hh. 98-103, diperoleh 30 September 2019 dari http://jurnal. ugm.ac.id/JKN.

\section{Internet}

https://id.wikipedia.org/wiki/Ancaman_ nonmiliter

https://id.wikipedia.org/wiki/Ancaman _ militer.

\section{Peraturan Perundangan}

Undang-Undang Nomor 3 Tahun 2002 Tentang Pertahanan Negara

Undang-Undang Nomor 20 Tahun 2003 Tentang Sistem Pendidikan Nasional

Undang-Undang Nomor 14 Tahun 2005 Tentang Guru dan Dosen

Permendiknas Nomor 41 Tahun 2007 Tentang Standar Proses Untuk Satuan Pendidikan Dasar dan Menengah 